\title{
MEMOIR
}

\section{LALGUDY S. VAIDYANATHAN}

L. S. VAIDYANATHAN, who died on 25 February 1962 at the agc of 68 , crowned a brilliant academic career with a 'first' at the M.A. Examination of the Madras University in I9I4 which earned for him the award of the Stuart Prize. His deep interest in mathematics attracted him to the teaching profession and he joined the Baroda College, Baroda, as a Professor of Mathematics. A scholarship from the Bombay Government launched him on his actuarial studies; he obtained the Fellowship of the Institute in 1926. He then joined the Oriental Government Security Life Assurance Co. Ltd. as Assistant Actuary and was simultaneously appointed a part-time Professor in Actuarial Science in the Sydenham College of Commerce and Economics, Bombay, in which latter capacity he launched several youthful aspirants on their actuarial careers. The growth of the actuarial profession in India is very largely the result of the missionary zeal he displayed in that sphere.

In 193 I he was entrusted by the Government of India with the work of conducting an investigation into the mortality of the Indian population based on the census data. His actuarial report, which was issued as an annexure to the Report on the Census of India, 193 I, distinguished itself for the knowledge, ingenuity and enthusiasm he displayed in the analysis of this most extensive census undertaking. His investigation into the mortality of Indian assured lives based on the experience of the 'Oriental' for the decade 1925-35 was a contribution of inestimable value to Indian life assurance. The investigation was comprehensive in its scope and its results met with widespread acceptance. His paper on the subject submitted to the Institute (F.I.A. 7o, 15) earned for him a research grant from the Sir George Hardy Memorial Fund.

Mr Vaidyanathan's first great opportunity to display his abilities to a wider circle came when he was nominated to the Central Legislative Assembly, when the Insurance Bill, later to be placed on the Statute Book as the Insurance Act, 1938 , was on the anvil. The legislation was complicated and comprehensive, and the then Law Member, Sir N. N. Sircar, paid a handsome tribute to his useful work in that connexion.

Next came the Income Tax Act. Mr Vaidyanathan had long held the view that the system then in vogue in India of taxing life assurance companies on the entire surplus disclosed by the actuarial valuation was very unfair. He played a leading part in getting the Income Tax Act amended to usher in a method of taxation which was just and fair. As a first step, exemption from taxation was given in respect of half the surplus reserved for the benefit of the policyholders, but, as the position was still unsatisfactory, he continued pressing the point. Ultimately in 1952 , the law was once again changed to exempt from income tax a higher quantum of the surplus reserved for the benefit of policyholders, which position continues to obtain today.

In the matter of taxation, there was another hardship, namely the method of assessment of Superannuation Funds. Mr Vaidyanathan's unremitting efforts in this connexion resulted in an amendment to the Indian Income Tax Act, whereby special provisions were introduced which conferred valuable concessions on approved Superannuation Funds. 
In I943, Mr Vaidyanathan's services were lent to the Government of India as Superintendent of Insurance. Apart from some legislation of an important nature put through during his term of office as Superintendent of Insurance, he served as the Member-Secretary of the Insurance Enquiry Committee appointed in 1945 to inquire generally into the manner of working of insurance companies. As a result of the findings and recommendations of that Committee, the Insurance Act was further amended in 1950. On the expiry of his term of office as Superintendent of Insurance, he reverted to the Oriental and was placed at the helm of affairs as Manager.

On nationalization of life insurance in India in 1956 , the Chief Executive of each of the companies except the 'Oriental' was replaced by a Custodian selected from a different company, but Mr Vaidyanathan alone continued with the 'Oriental', but as Custodian, indicative of the Government's recognition of his unique ability and high principles.

On the establishment of the Life Insurance Corporation, he was appointed Managing Director of the Corporation, which post he continued to occupy for the remaining years of his active service.

K. R. SRINIVASAN 